\title{
Migration of Health Personnel: Between Human Rights and International Legal Regulation of Migration
}

\author{
Ekaterina V. Kiseleva \\ Candidate of Legal of Sciences (PhD), Associate Professor \\ Department of International Law, Law Institute, Peoples' \\ Friendship University of Russia (RUDN University), 6 \\ Miklukho-Maklaya st., Moscow, 117198, Russia \\ E-mail: kiseleva_ev@rudn.university
}

\author{
Anastasia A. Belousova \\ Candidate of Legal of Sciences (PhD), Senior Lecturer, \\ Department of International Law, Law Institute, Peoples' \\ Friendship University of Russia (RUDN University), 6 \\ Miklukho-Maklaya st., Moscow, 117198, Russia
}

\begin{abstract}
Migration of health personnel is a phenomenon that is governed by law at the intersection of the tendencies peculiar to human rights protection as a branch of public international law and to international legal regulation of migration. However, this intersection looks like not realized by the states and is quite different from the increasing role of the human rights-based approach in the international legal regulation of migration. In a part of human rights protection, the extensive work is carried out by the World Health Organization and the United Nations treaty bodies, who detail the content of the right to health. In a part of international legal regulation of migration, the sensitivity of states towards taking additional legal commitments regarding the international movements of people remains. Upon that being states, while the human rights-based approach towards migration represents generally the application of existing treaty obligations of states in the field of human rights to migration sphere, migration of health personnel reveals that the states strive to remain in frames of ethical, not legal impositions, even if that demands the distortion of the most important international legal documents.
\end{abstract}

Keywords-International law; Migration; Migration of health personnel; WHO - World Health Organization; WHO Global Code of Practice 2010; SDGs - Sustainable Development Goals

\section{INTRODUCTION}

The problem of health personnel migration is being voiced at the international level for more than half a century by now. In the 60-s of the XX century this problem was raised among the problems of brain drain from the developing states, e.g. [1], but in the 70-s of the same century it gained separate attention [2]. In 2004 the resolution of the World Health Assembly got the self-explanatory title 'International migration of health personnel: a challenge for health systems in developing countries' (WHA57.19 from 22 May, 2004) [3]. The linkage of migration problems and human rights protection problems is evident, as evident is the conceptual and strategic character of this linkage.

Solvation of the intersecting problems seems to follow the model of the inter-state cooperation in the field of migration.

The article was prepared in frames of the Project 16-03-50188 supported by the Russian Foundation for Humanities.
In a part of human rights, there is a range of specific legal obligations that can be refracted to migratory issues, a list of monitoring mechanisms, etc., but in a part of migration the states try to maintain as much and as full their sovereign prerogatives, as is possible. The latter explains the great role of legally non-binding cooperation structures and documents in the field of migration.

The World Health Organization (hereinafter WHO) undertakes considerable efforts to improve the realization of the right to health. Inter alia, WHO elaborated the Global Code of Practice on the International Recruitment of Health Personnel (hereinafter Code). However, the realization of the Code by the states illustrates the above formulated specificity of the inter-state cooperation developing along the model of states interaction about the issues of migration, not that of the human rights protection.

\section{WORLD HEALTH ORGANIZATION AND THE HUMAN RIGHT TO HEALTH: THE ISSUE OF HEALTHCARE SYSTEMS}

International cooperation in the field of ensuring the quality of healthcare is carried out within and under the auspices of international intergovernmental organizations. One can note here the important role of the specialized agencies and programs of the United Nations, especially WHO, which is entrusted with the realization of the right to health at the international, regional and national levels. In developing and implementing national health strategies, States should use technical assistance and cooperation with the WHO. In addition, states have the opportunity to benefit from the extensive information and advisory services from the WHO for collecting and disaggregating data and identifying indicators and benchmarks relevant to the right to health.

One of the main obligations with regard to the right to health [4] is the requirement that states should adopt national public health strategies and action plans that take into account the health needs of their whole respective populations, based on available epidemiological data. The strategies and action 
plans should be periodically reviewed in accordance with the principle of public participation and the principle of transparency.

Important assistance to states in the elaboration of national health programs is provided by the WHO, who has always been at the forefront in developing health strategies and action programs, e.g., WHO is preparing recommendations for national health programs that deal with almost all key issues of public health: monitoring the epidemiological situation; the development of vaccination and immunization programs, programs for the protection of maternal and child health, programs to combat epidemics of influenza and other infectious diseases; treatment of tuberculosis, malaria, hepatitis, measles, rubella; the use of vitamin preparations and vitally important minerals in the form of food supplements by children and pregnant women; combating the spread of infections; blood transfusion; treatment of mental disorders; maintenance of air quality at the proper level; personal hygiene; necessary physical activity; the use of dehydrating drugs and the management of pain syndrome; diagnosis of children for HIV/AIDS and others.

With regard to national healthcare plans for the world's poorest countries with the poorest population, in 2005, WHO developed the "Human Rights, Health and Poverty Reduction Strategies" Program [5; 6]. The Program provides for recommendations to the WHO Member States in respect of the development of "a pro-poor health strategy based on human rights principles" in order to take into account and solve problems related to the vital interests of the most socially vulnerable groups of the population. In preparing any national plan, states should, first of all, develop a strategy that would cover all people and every person, no matter how poor or socially alienated they are, since without the participation of the poorest of the society, those who are involved in the development of a national strategy and action plans risk basing their strategies and action plans on incorrect starting points and misunderstanding their tasks and, at the same time, not using the opportunities that can bring genuine changes and reverse the situation.

Similar issues are also touched upon in a document prepared by the United Nations (hereinafter UN), entitled "Final draft of the guiding principles on extreme poverty and human rights", submitted by the Special Rapporteur on extreme poverty and human rights [7].

In the WHO report "Strategy for protection of health, human rights and poverty reduction" mentioned above, the planning bodies working in the Ministry of Health system must build health policy in accordance with the needs and needs of the poorest sections of society. When planning health problems, it is necessary to rely on the principles of compulsory observance of human rights, which makes it possible to address in parallel many other tasks that may not necessarily be relevant for the work of the Ministry of Health in planning its activities.

In the above mentioned WHO report "Human Rights, Health and Poverty Reduction Strategies", the planning bodies working within ministries of health must build health policy in accordance with the needs of the poorest sections of the society. When setting the tasks regarding the healthcare, it is necessary to rely on the principles of compulsory observance of human rights, which makes it possible to address in parallel many other tasks that may not necessarily be relevant for the work of the respective Ministry of Health in planning its activities.

The Special Rapporteur on the right to health outlined the provisions that explain common approaches to the use of the right to the highest attainable standard of health for strengthening health systems. The report of the Special Rapporteur, made in 2008 and devoted to healthcare systems, addresses seventeen provisions on such issues as the need for transparency; involvement of the population in solving healthcare systems problems; non-discrimination; the importance of adopting disease prevention programs; the importance of well-coordinated action and international cooperation; the main international obligations of States on the right to health, etc.

WHO analyzes the situation in healthcare in all its Member-States and, on basis of the results obtained, provides all possible assistance, including technical assistance in health planning [8]. For economically developed countries, WHO is limited to a general analysis of the health protection situation, indicating the main risks to human health, such as alcoholism, tobacco smoking, or high rates of injury and deaths from accidents. At the same time, with respect to the less economically developed countries, in addition to general recommendations, WHO is also developing cooperative action strategies, which involves deeper elaboration of topics and issues, as well as assistance to national health systems.

When planning national healthcare, it is necessary, first of all, to create a data bank that can then be controlled and evaluated, when monitoring the overall situation so that all goals in the field of health care, that were set, are achieved or that the formulated tasks have not been implemented, while at the same time possessing the necessary information showing the reasons why the goals could not have been achieved.

This last aspect was highlighted by the Special Rapporteur on the right to health in his report of 10 October, 2003. In fact, the inclusion of indicators has now become a common practice in the design of health programs at the national, regional and global levels. Among the most important indicators formulated in the Millenium Development Goals (hereinafter MDGs) are three indicators about health. These are an indicator related to the reduction of child mortality (MDG No. 3), the maternal health indicator (MDG No. 5) and the indicator related to the fight against HIV/AIDS, malaria and other infectious diseases (MDG No. 6). In 2015 the MDGs were substituted the Sustainable Development Goals [9]. The overall health indicators developed by the WHO are equally important. These indicators are based on the reports of the World Health Statistics, which assess the level and state of health in each individual country and in the world as a whole. 


\section{The WHO Global CODE OF PRACTICE ON THE INTERNATIONAL RECRUITMENT OF HEALTH PERSONNEL}

After several decades of developing the idea and several years of elaboration, on 21 May, 2010, the World Health Assembly, in accordance with the decision of 193 MemberStates of the WHO, adopted the WHO Global Code of Practice on the International Recruitment of Health Personnel (WHA63.16 from 21 May 2010). The question is, whether the world's response to the challenges to realization of the right to health posed by the migration of health personnel changes over the past five decades, or specifically since the adoption of the Global Code. This is a question, the answer to which is simple, but hardly optimistic.

The Code is small in volume - there are only ten articles in it. In the first article the objectives of the document is formulated, in the second we have the nature and scope of its application. Article 3 includes 8 paragraphs containing guiding principles. Article 4 is devoted to responsibilities, rights and recruitment practices. Article 5 is called "Health workforce development and health systems sustainability". Article 6 refers to data gathering and research, article 7 is about the information exchange. The eighth article contains provisions on the implementation of the Global Code, the ninth is about monitoring and institutional arrangements, and the tenth article deals with partnerships, technical collaboration and financial support.

In respect of the topic under consideration, several key issues can be identified, they are the nature of the Global Code and the principles it contains, the balance of problems / interests / positions of developed and developing countries, the principle of mutual benefit, the correlation between the right to freedom of movement of health personnel with the right to health of the health personel's compatriots, remaining in the homeland, the existence and improvement of the factual basis and a number of others.

Concerning the first aspect noted above, the Global Code itself establishes that it is "voluntary" (paragraph 2.1.) and "contains ethical principles" (paragraph 2.3.). Some states, e.g. Japan, Canada particularly insisted on the voluntary nature of the document during the developement of the Code [10]. And what is meant by the "ethical" nature of the principles, repeatedly underlined in the text (paras. 1, 4 Art. 1, para. 2.3. Art. 2, para. 4.3. Art. 4 of the Code), was and remains unclear. The United States of America, for example, heard this as an "overly judgmental tone" [10].

The second highlighted problem allows us to make a radical difference between examining the problems of migration of health personnel in the initial and current stages. If the first documents on the topic always clearly indicated the actual beneficiaries (developed countries) and those actually enduring losses (developing countries), then the further, the more the mixture and distortion of the picture takes place. Let us give just one example.

As it is noted in the third preambular paragraph of the Global Code, "adequate and accessible health workforce is fundamental to an integrated and effective health system and for the provision of health services". The next paragraph expresses deep concern that "the severe shortage of health personnel, including highly educated and trained health personnel, in many Member States, constitutes a major threat to the performance of health systems and undermines the ability of these countries to achieve the Millennium Development Goals and other internationally agreed development goals". The second quotation contains a very euphonious, but significant mixture of completely different positions and interests.

The shortage of medical personnel is a problem for both developed and developing countries. However, if the former demand more the nursing (auxiliary medical) personnel to care for the aging population [11], the latter need people capable of providing first aid, e.g. according to the WHO data, $80 \%$ of the disabled persons live in low-income countries [12]. Developed states act as employers of foreign medical personnel, and developing countries lose professional staff, which is even not enough to meet their own health needs.

The Millennium Development Goals (UN Doc. $\mathrm{A} / \mathrm{RES} / 55 / 2$ ) in their part on the fight against specific diseases mention HIV / AIDS (subparas. 4, 5 para. 19, subpara. 4 para. 28 of the Declaration), malaria (subpara. 4 para. 19), other "major diseases that afflict humanity" (ibidem.) and "other infectious diseases" (subpara. 4 para. 28). Taking into account that these words are located in the sections on "Development and poverty eradication" and "Meeting the special needs of Africa", it becomes apparent that the noble-sounding wording of the Global Code distorts the perception of the needs for medical personnel in comparison to different regions of the world. In 2006, in the World Health Report [13], WHO singled out a group of 57 states where the deficit of doctors, nurses and midwives is critical. None of these 57 states are developed. Similar confusion and distortion as noted above can be traced throughout the Global Code. On the contrary, the "mutual advantage" of international recruitment of health personnel almost became the title of one of the articles of the code (Art. 5 of the Draft for discussion dated 18 August 2008, of the Draft in the version dated 4 December 2008, 3 December 2009, 8 April 2010.

In accordance with Art. 9.1. of the Global Code, "States should periodically report the measures taken, results achieved, difficulties encountered and lessons learned", and the World Health Assembly is "to periodically review the relevance and effectiveness of the Code" (Article 9.5.).

By December, 2017, there were two rounds of review.

The first round of this review was held in 2013 [14]. What were its results? 56 countries reported on the current status of the Code implementation process, of which 37 have taken certain steps to implement the Code [14]. The national authorities, as required by the Art. 7.3. of the Code, were designated in 85 countries [14]. As a result, there is a discrepancy between the reports received from the Member States and the commitments undertaken in connection with the unanimous approval of the Code [15]. However, the discrepancy was very predictable given the meagerness of the 
prescribed measures for some states (those possessing the resources and submitting materials) and the meager resources for solving existing complex problems for others (developing countries who, in the absolute majority, did not submit the materials).

The second round of the review was completed in 2015 [16]. The overall coverage of designated authorities and reporting "improved considerably", counting for 117 designated national authorities and 74 of them reporting [16, para. 7, Table 1] and fixing the emergence of the new themes, e.g. requests for technical assistance, etc. [16, para. 13]. The experts note, however, that the dissemination of the Code remains poor, the support for the implementation of the Code remains limited and the WHO leadership is still lacking [17].

\section{CONCLUSIONS}

The authors' view is that the WHO Global Code of Practice on the International Recruitment of Health Personnel, 2010, has a negative and positive significance at the same time. On one hand, it is regrettable that the document allows to mix the distinct degrees of vulnerability of developed and developing countries in the issue in question, urging developed states to act on basis of hardly binding "ethical principles" for the international recruitment of health personnel. On the other hand, it is encouraging that this document has been adopted at least as the example of the evidence of the existence of the problem.

With regard to the systemic approach to international legal regulation of migration, the Global Code confirms that in the sphere of migration, states tend to take as few international legal obligations as possible, even in the situation when migration problems intersect with other established spheres of interaction between states.

Although the migration of medical personnel is a complex phenomenon that can be viewed from different perspectives (that of receiving states and of sending states, that of human rights and of labour migration), the issues raised by it are generally tackled following the tendencies that are characteristic of the international legal regulation of migration as a whole.

\section{REFERENCES}

[1] Outflow of trained personel from developing countries. Resolution by the UN General Assembly 2320 (XXII), 15 December 1968.

[2] Preparing the national health systems personnel. WHO Director-General Annual Report. A/25/7, A/25/8, 13 April 1972.

[3] A.A. Belousova, "The right to health in international law: history of formation," Bull. of the Peoples' Friendship University of Russia, Law Series, 2013, vol. p. 270-278.

[4] Committee on Economic, Social and Cultural Rights. General comment No. 14: The right to the highest attainable standard of health, 11 August 2000, UN Doc. E/C.12/2000/4.

[5] "Human Rights, Health and Poverty Reduction Strategies", Draft, Health and Human Rights Publications Series, Issue No 5, April 2005, WHO/ETH/HDP/05.1.

[6] "Human Rights, Health and Poverty Reduction Strategies", WHO, Health and Human Rights Publications Series, Issue No 5, December 2008.

[7] Final draft of the guiding principles on extreme poverty and human rights, submitted by the Special Rapporteur on extreme poverty and human rights, Magdalena Sepúlveda Carmona. 18 July 2012. UN Doc. A/HRC/21/39.

[8] A.K. Abashidze, A.A. Belousova, "Right to Health: International Legal Dimension in the Globalization Context," Indian Journal of Science and Technology, Vol 9(39), DOI: 10.17485/ijst/2016/v9i39/103426, October 2016, p. 1-6.

[9] A.K. Abashidze, A.M. Solntsev, E.V. Kiseleva, A.E. Koneva, D.A. Kruglov, "Achievement of Sustainable Development Goals (2015-2030) International legal dimension," Indian Journal of Science and Technology, Vol 9(37), DOI: 10.17485/ijst/2016/v9i37/102168, October 2016, p. 1-9.

[10] International recruitment of health personnel: draft global code of practice. 15 April, 2010. WHO Doc. A63/ INF.DOC./2.

[11] G.I. Gluschenko, V.A. Ponomarev, "Migration and Development," Moscow: Economica, 2009, p. 91-94 (in Russ.; Глущенко Г.И., Пономарев В.А. Миграция и развитие. М.: Экономика, 2009. С. 9194).

[12] Disability, including prevention, management and rehabilitation: report by the Secretariat, WHO, 14 April, 2005, A/58/17.

[13] The World Health Report 2006 - working together for health, WHO, 2006.

[14] Siyam A., Zurn P. et al. "Monitoring the implementation of the WHO Global Code of Practice on the International Recruitment of Health Personnel," Bulletin of WHO, 2013, Vol. 91, p. 816-823.

[15] WHO policy dialogue on international health workforce mobility and recruitment...: technical report, Amsterdam, 2-3 May, 2013, WHO, 2013 (in Russ.; Диалог по вопросам политики ВО3 для преодоления проблем, связанных с международным наймом и мобильностью персонала здравоохранения: технический доклад. Амстердам, 2-3 мая 2013 г. ВО3, 2013. С. 7).

[16] WHO Global Code of Practice on the International Recruitment of Health Personnel: second round of national reporting, WHO, 24 March, 2016, A69/37.

[17] I. Dhillon, “Assessing the Code's Effectiveness: Reflection on Emerging Evidence," $2^{\text {nd }}$ Expert Advisory Group Meeting, 27 April, 2015. 